\title{
PEDAGOGICKÉ KOMPETENCE V CENTRU POZORNOSTI KONFERENCE ICOLLE 2021
}

Schopnosti, jako jsou správné nastavení vzdělávacího cíle, vhodně zvolená vzdělávací metoda, srozumitelné předávání odborných poznatků, spravedlivé hodnocení nebo komunikace s různorodou skupinou studentů, nejsou dosud u pedagogů vždy samozřejmostí. Odbornost učitelů, at' už na vysokých, či středních školách, je důležitým předpokladem pro kvalitní výuku. Ale neméně důležité jsou i rozvinuté pedagogické kompetence. A právě na rozvoj kompetencí učitelů se zaměřili odborníci na mezinárodní vědecké konferenci ICOLLE 2021, kterou upořádal Institut celoživotního vzdělávání MENDELU. Konference se konala pod záštitou rektorky Mendelovy univerzity v Brně Danuše Nerudové a hejtmana Jihomoravského kraje Jana Grolicha.

Potřeba neustálého rozvoje pedagogických kompetencí na všech stupních škol se v dnešní době skloňuje ve všech pádech a nedávný lockdown anucená online výuka je ještě znásobily. Jak přistupují školy k rozvoji pedagogických kompetencí svých učitelů a jak školy motivují začínající učitele zaznělo v dopolední plenární části konference. Tu slavnostně zahájili prorektor pro vzdělávací činnost na MENDELU Radim Farana a ředitel Institutu celoživotního vzdělávání Petr Adamec.

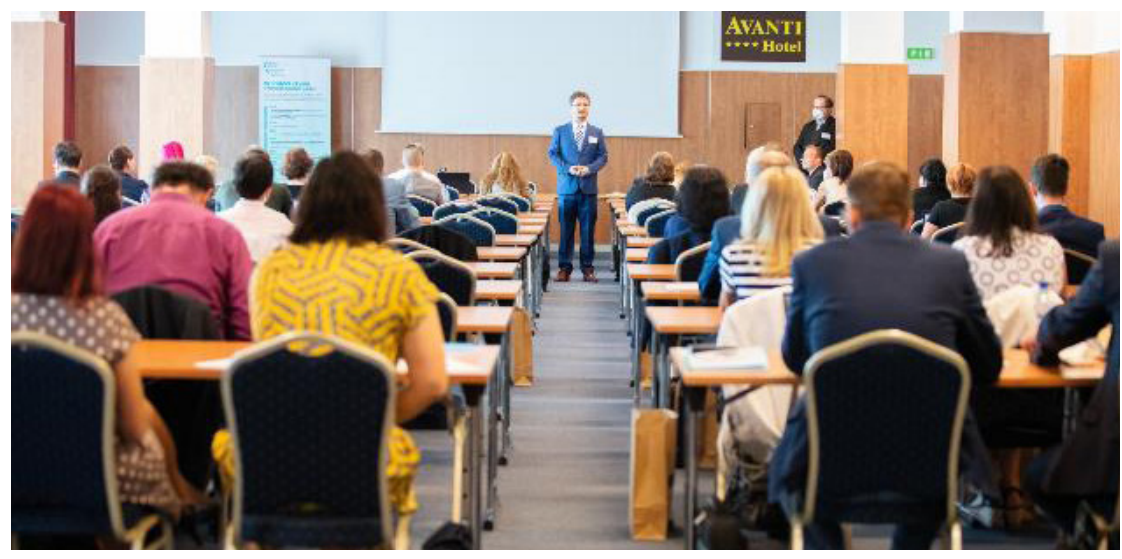


Pětileté zkušenosti s budováním systému dalšího vzdělávání vysokoškolských učitelů na Žilinské univerzitě prezentovala Lucia Hrebeňárová, ředitelka Ústavu celoživotního vzdělávání Žilinské univerzity. Doplnění a rozvoj svých pedagogických kompetencí nevnímali zpočátku učitelé jako potřebné. Průzkum mezi studenty ale poukázal na slabé stránky ve výuce, např. v učebních metodách, ve vedení výuky nebo v hodnocení studentů. Díky výsledkům průzkumu, s pomocí př́kladů dobré praxe z evropských univerzit, ale zejména po zavedení standardů pro vnitřní systém zabezpečení kvality vysokoškolského vzdělávání na slovenských školách došlo na Žilinské univerzitě ke změně vnímání potřeby dalšího vzdělávání pedagogů. Velmi důležitou roli ve změně vnímání sehrála i podpora vedení univerzity a začlenění vzdělávání učitelů do rozpočtu univerzity. Do budoucna plánují na Žilinské univerzitě převést izolované kurzy inženýrské pedagogiky do systému dalšího vzdělávání vysokoškolských pedagogů a simulovat vznik učící se profesní komunity učitelů.

Jakým zpo̊sobem řeší rozvoj pedagogických kompetencí na Masarykově univerzitě v Brně, prezentoval Petr Sucháček z Filozofické fakulty Masarykovy univerzity. Svůj prríspěvek zaměřil na vznik a fungování Centra rozvoje pedagogických kompetencí CERPEK. Shrnul, jaké postupy a nástroje se při budování centra osvědčily, a zmínil i přešlapy a omyly, kterým se v začátcích on a jeho kolegové nevyhnuli, ale díky nimž se centrum mohlo posunout dál. Za klíčový moment ve fungování CERPEK považuje podporu z vedení univerzity. Osvědčilo se rovněž propojení akademiků napříč fakultami a mezigenerační propojení akademiků. Za nejlepší způsob propagace dalšího vzdělávání pedagogů považuje tzv. šeptandu, tedy dobré reference od spokojených účastníků vzdělávání. V centru si zakládají na příjemné atmosféře, kvalitních lektorech a smysluplném obsahu kurzů a v budoucnu by rádi vybudovali komunitu mezi účastníky pedagogického vzdělávání.

O kompetenčním modelu LADDER, který slouží k vytvoření plánu rozvoje u začínajících učitelů, hovořila ve svém příspěvku Leslie Blanchardová, ředitelka Leadership Development Institute (LDI) na Louisiana State University. USA se potýká s problémem fluktuace a častých odchodů pedagogů ze škol. K tomu se navíc přidává i syndrom vyhoření, umocněný epidemií covid-19. Blanchardová zmínila, že v USA každý školní den odejde téměř tisíc učitelů ze školství a už se nikdy nevrátí, a dalších tisíc učitelů přejde na jinou školu z důvodů hledání lepších pracovních podmínek. To vše zatěžuje rozpočet Spojených států částkou přibližně 4,9 miliard dolarů. 
Tyto skutečnosti byly pro LDI impulsem k vyvinutí kompetenčního modelu LADDER. Ten v procesu hodnocení za pomoci speciálních karet identifikuje u pedagogů jejich silné stránky, přirozené (standardní) dispozice a stresory. Stresory jsou přitom dispozice, které způsobují frustraci a vyžadují rozvoj. Na základě hodnoticího procesu a sebereflexe učitele připraví kouč tzv. StepLADDER neboli plán rozvoje daného učitele. Jeho cílem je zlepšovat duševní zdraví učitelů a zabránit jejich odchodům ze školství. Model LADDER slouží v současnosti pro pedagogy, do budoucna jej chce LDI upravit napřr. i pro oblast právní, zdravotnickou nebo pro studenty.

Konference ICOLLE proběhla letos u př́ležitosti 15. výročí vzniku Institutu celoživotního vzdělávání (ICV) jako samostatného vysokoškolského ústavu. Dobu vzniku ICV a jeho rozvoj připomenul Pavel Máchal, emeritní ředitel Institutu celoživotního vzdělávání. Ten se na svém počátku věnoval organizaci asi dvaceti kurzů a vzdělávání na univerzitě třetího věku. Dnes má ICV ve své nabídce více než šedesát odborných, jazykových či zájmových kurzů, realizuje vzdělávání na Univerzitě třetího věku, na Mezigenerační univerzitě a poskytuje širokou paletu poradenských služeb pro celou Mendelovu univerzitu. Už od svých počátků se ICV věnuje také vzdělávání budoucích učitelů na středních odborných školách formou bakalářského studia i formou kurzů. V současné době organizuje ICV i řadu aktivit zaměřených na rozvoj pedagogických dovedností pro akademiky z Mendelovy univerzity, např. jak vybrat a aplikovat vhodné metody online výuky nebo jak hodnotit v distanční a online výuce.

Po plenární části pokračovala konference ICOLLE jednáním v odborných sekcích, kde měli účastníci konference prostor k vzájemné diskusi, sdílení zkušeností a př́kladů dobré praxe. Příspěvky se věnovaly tématům spojeným s komplexním rozvojem pedagogických a akademických pracovníků, aktuálním výzvám ve školství a na trhu práce, flexibilním formám vzdělávání a fenoménu internacionalizace.

ICOLLE 2021 v řeči čísel: 13. ročníku konference, která se konala u příležitosti 15. výročí vzniku ICV MENDELU, se zúčastnilo více než šedesát odborníků z pěti zemí včetně Spojených států amerických. V úvodní části konference zazněly čtyři plenární př́spěvky, v osmi odborných sekcích vystoupili řečníci s padesáti příspěvky. Všechny příspěvky z letošního ročníku konference celoživotního vzdělávání ICOLLE budou zájemcům $\mathrm{k}$ dispozici v recenzovaném sborníku prríspěvků, který bude zveřejněn na stránkách www.icolleconference.cz. 


\section{Autor zprávy}

Ing. Martina Urbánková

Mendelova univerzita v Brně, Institut celoživotního vzdělávání, Zemědělská 814/5, 61300 Brno, Česká republika

email: martina.urbankova@mendelu.cz

Přijato: 12. 9. 2021

Link to this article: https://doi.org/10.11118/lifele20211102191 